\title{
Seasonal Variation of Cochlodinium polykrikoides in the North of Oman Sea (Iranian Waters)
}

\author{
Fereshteh Saraji ${ }^{1}$, Wan Maznah Wan Omar $^{2}$ and Mahmood Ebrahimi ${ }^{1}$ \\ 1. Department of Ecology, Persian Gulf and Oman Sea Ecological Research Institute, Bandar Abbas 79167-93165, Iran \\ 2. Department of Biology, School of Biological Science, Universiti Sains Malaysia, Penang 11800, Malaysia
}

\begin{abstract}
This study was carried out to investigate the Cochlodinium polykrikoides fluctuations in the north of Oman Sea during preand post-monsoon season in 2008. The study area was divided into 10 transects (T1-T10) from the Strait of Hormuz (T1) to Gwadar (T10) which cover the whole of the Iranian waters in the Oman Sea. The results showed that at first, Cochlodinium polykrikoides appeared in the northeast part (T10) in the pre-monsoon season, then it spread to other parts of the study area. Cochlodinium polykrikoides was observed in greater abundance in the Strait of Hormuz in the post-monsoon season. The results demonstrated that T10 (transect 10) had the highest abundance in the pre-monsoon season. The Kruskal-Wallis test showed a significant difference among transects $(P<0.05)$. The present study showed that the abundance of Cochlodinium polykrikoides increased from coastal to offshore waters in the pre-monsoon season; however, in the post-monsoon season, there was a higher abundance in coastal waters compared to the offshore zone. It could be seen that the abundance of Cochlodinium polykrikoides started in offshore waters, then increased in coastal waters. During the pre-monsoon season, water discoloration was not observed, however, the water changed to brown from T1 to T4 (northwest) and blooms of Cochlodinium polykrikoides was recorded in the post-monsoon season.
\end{abstract}

Key words: Pre-monsoon, post-monsoon, coastal and offshore, Strait of Hormuz.

\section{Introduction}

Cochlodinium polykrikoides is an unarmoured marine dinoflagellate species with spiral shape and variable size (30-40 $\mu \mathrm{m}$ in length and 20-30 $\mu \mathrm{m}$ in width). A reddish orange pigment body is located at the dorsal side of the epicone [1]. This species commonly occurs in warm-temperate and tropical waters [2].

In Asian waters, this species was first observed in the Yatsushiro Sea, Japan in 1976 and coincided with huge economic damage. It also occurred in Japan and Korea in recent years. In addition, Cochlodinium polykrikoides was first detected in the Philippines in 2002 and then the coastal waters of Hong Kong and Sabah, Malaysia [3, 4].

Cochlodinium polykrikoides has caused high mortality in marine organisms in many places, such as

\footnotetext{
Corresponding author: Fereshteh Saraji, Ph.D., research field: marine science-planktology. E-mail: saraji20042000@yahoo.ca.
}

western Japan, the southern coasts of Korea, and the north of Persian Gulf [5, 6].

Most algal blooms are harmless and actually benefit the aquaculture and wild fisheries. However, some of them influence the marine life under exceptional conditions and can kill fish and invertebrates [7].

The aims of the present paper are to determine the temporal and seasonal variations of Cochlodinium polykrikoides in the north of Oman Sea during the preand post-monsoon season in 2008 from coastal to offshore zones.

\section{Material and Methods}

\subsection{Study Area}

The study was carried out in the north of the Oman Sea covering all Iranian waters from the Strait of Hormuz to Gwadar which include 10 transects (T1-T10, Fig. 1). Phytoplankton samples were collected during the pre- and post-monsoon season in 2008 along the coastal and offshore zones. 




Fig. 1 The study area and location of sampling sites.

\subsection{Phytoplankton Sampling and Analysis}

A Rosette sampler was used to collect phytoplankton samples. Three replicate samples $(2 \mathrm{~L}$ each) were collected randomly from each site (T1-T10). One sample for each site was kept alive in a cool temperature for identification and another samples preserved in Lugol solution and sodium thiosulphate for counting. Nikon inverted and fluorescence microscope at 100 to 400 magnifications was used for identification. Cell counts were done using a Sedgewick-Rafter counting chamber and identified according to the morphological criteria given in taxonomic guides and descriptions in Refs. [8-13].

The total number of Cochlodinium polykrikoides cells present in $1 \mathrm{~L}$ of sample was calculated using the following formula (Eq. (1)):

$$
N=(n \times v) / V
$$

where, $N=$ total number of Cochlodinium polykrikoides (cells $\left.\mathrm{L}^{-1}\right), n=$ average number of
Cochlodinuim polykrikoide (cells $\left.\cdot \mathrm{mL}^{-1}\right), v=$ volume of concentrated plankton $(\mathrm{mL})$, and $V=$ volume of total water filtered (L). Determination of cell abundance was based on average cell counts calculated from the replicate samples. Relative abundance (\%) was calculated and recorded for each transect during each season and from coastal to offshore zones.

\subsection{Statistical Analysis}

The $t$ test was used to determine significant difference of cell abundance between two seasons. Non-parametric Kruskal-Wallis test was used to compare among different zones. This test showed only significant difference. If a significant difference was detected, Mann-Whitney $U$ test was used to identify the difference between zones [14]. All data were analyzed using SPSS software version 20 and Excel 2007 was used for drawing figures. ArgGis was used for drawing the distribution map. 


\section{Results and Discussion}

\subsection{Identification}

Cochlodinium polykrikoides was observed in April in the northeast of the Oman Sea (T10). Fig. 2 shows chains of Cochlodinium polykrikoides cells. Preservation with Lugol's solution did not produce good cells for observation because dark points were observed under microscope (Fig. 3a), and Fig. 3b shows the deformation and gelatinous form of Cochlodinium polykricoides. It was observed that when Lugol's and thiosulphate were used for preservation, better cells for observation under light microscope were produced (Fig. 2).

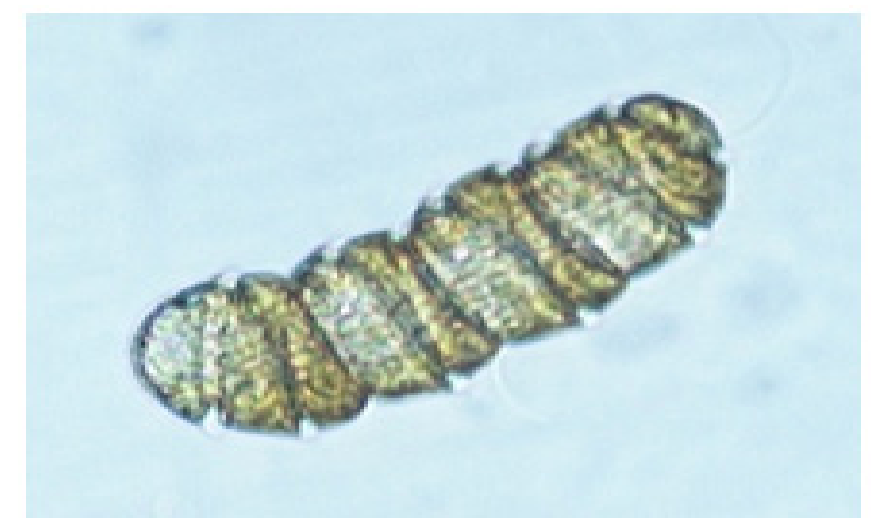

\subsection{Spatial and Temporal Distribution of Cochlodinium polykrikoides}

During the pre-monsoon season, the highest abundance was observed in T10 (transect 10) and decreased toward T1 (transect 1), while in the post-monsoon season, T1 showed the highest abundance compared to other transects (Fig. 4). During the pre-monsoon season, water discoloration was not observed, however, the water changed to brown from $\mathrm{T} 1$ to $\mathrm{T} 4$ and blooms of Cochlodinium polykrikoides was recorded in the post-monsoon season.

Cochlodinium polykrikoides was observed more in

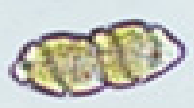

Fig. 2 Chains of Cochlodinium polykrikoides were obsereved in the north of the Oman Sea (magnification 100×).

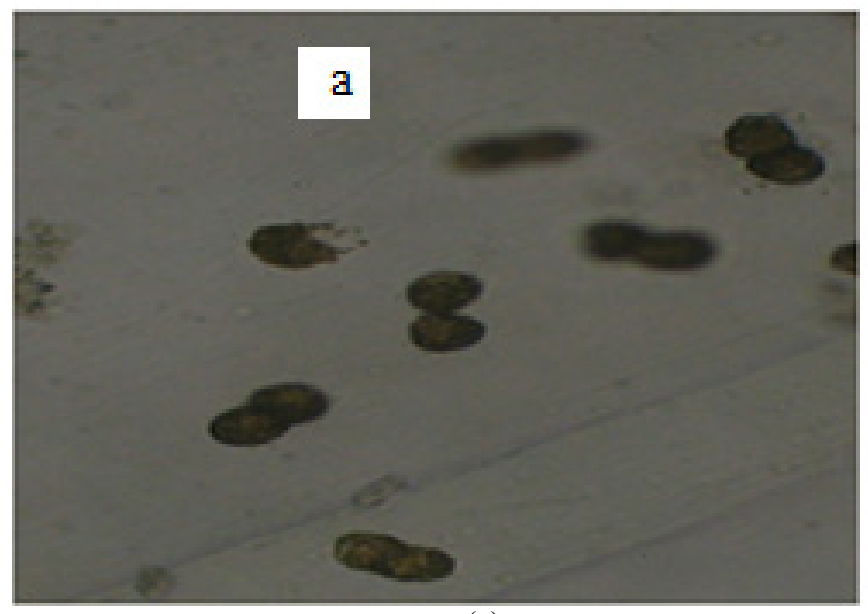

(a)

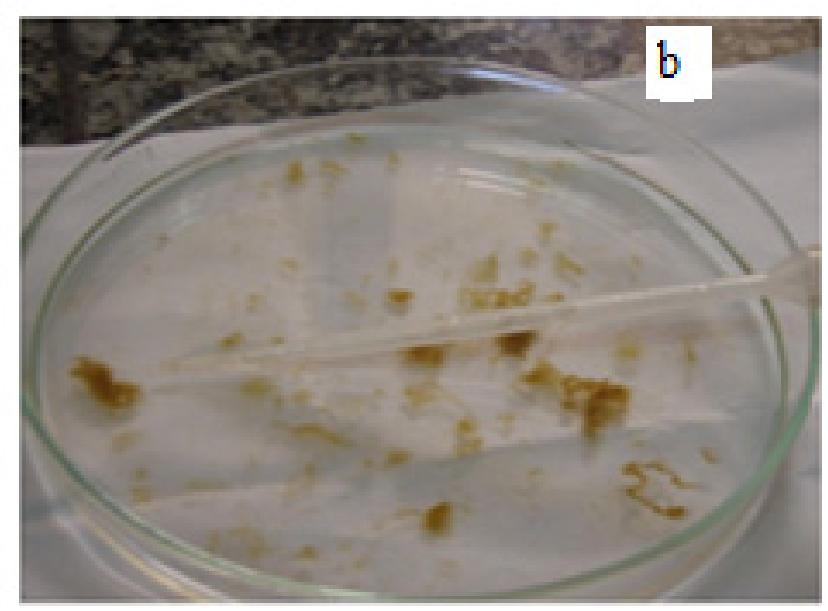

(b)

Fig. 3 (a) Deformation of Cochlodinium polykrikoides (dark point); (b) mucilage of Cochlodinium polykrikoide. 


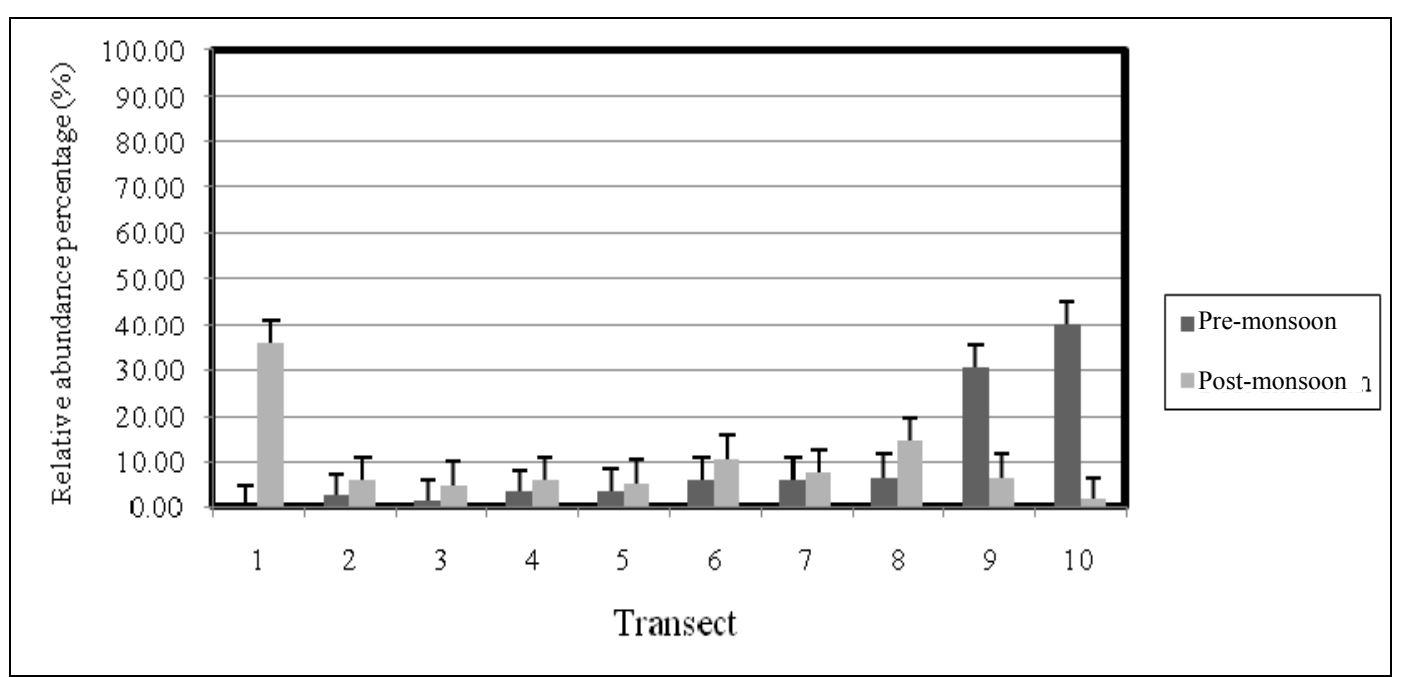

Fig. 4 Relative abundance (\%) of Cochlodinium polykrikoides among transects during pre-monsoon and post-monsoon seasons in 2008.

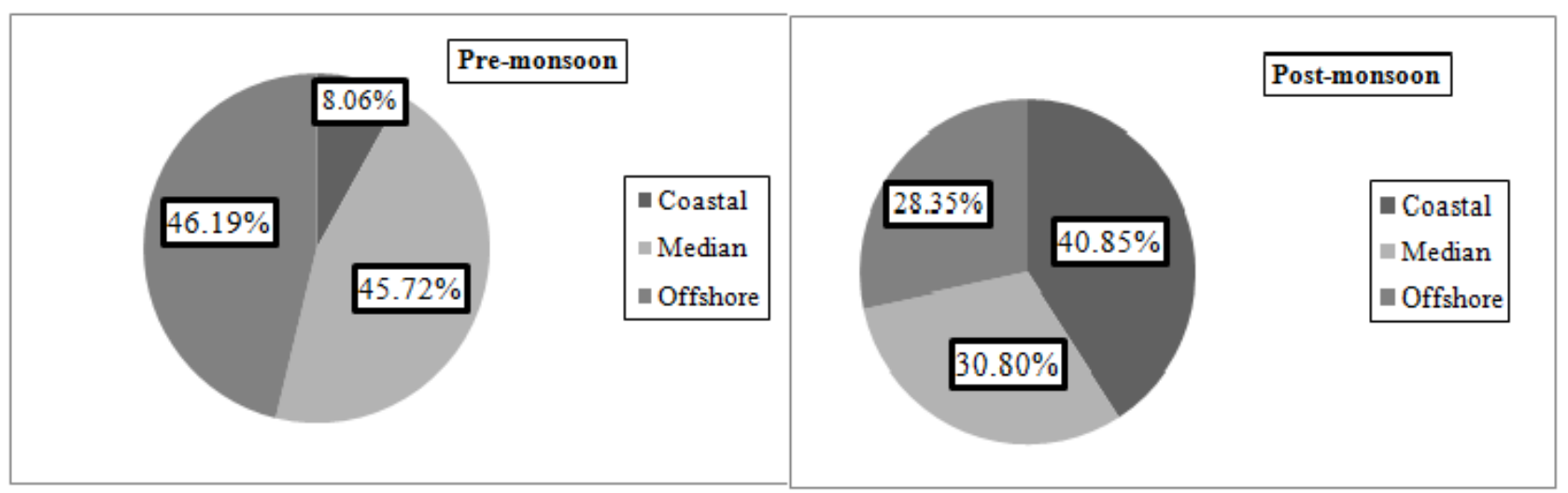

Fig. 5 Relative abundance (\%) of Cochlodinium polykrikoides from coastal to offshore zones during pre- and post-monsoon season in 2008.

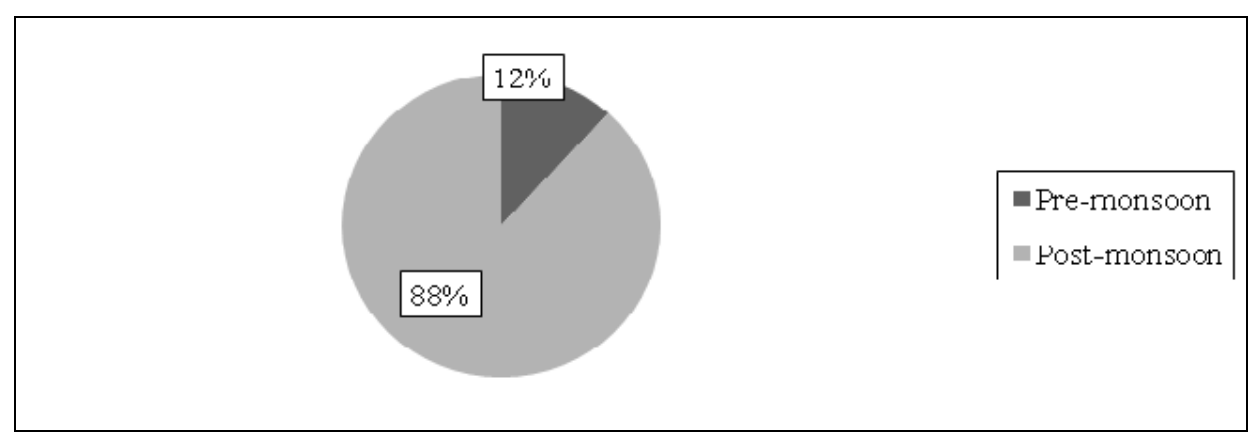

Fig. 6 Relative abundance (\%) of Cochlodinium poykrikoides during pre- and post-monsoon season in 2008.

offshore waters in the pre-monsoon season (46.19\%) and was lower in coastal waters $(8.06 \%)$, while in the post-monsoon, coastal waters showed higher abundance (40.85\%) (Fig. 5). Statistical test showed no significant difference among zones $(P>0.05)$. The abundance of Cochlodinium polykrikoides gradually increased from offshore towards coastal waters.

The results showed that the abundance of Cochlodinium polykrikoides increased from the pre-monsoon $(12.12 \%)$ to the post-monsoon season $(88.88 \%)$ (Fig. 6). The $t$ test showed a significant difference between the two seasons $(P<0.05)$. 




(a)

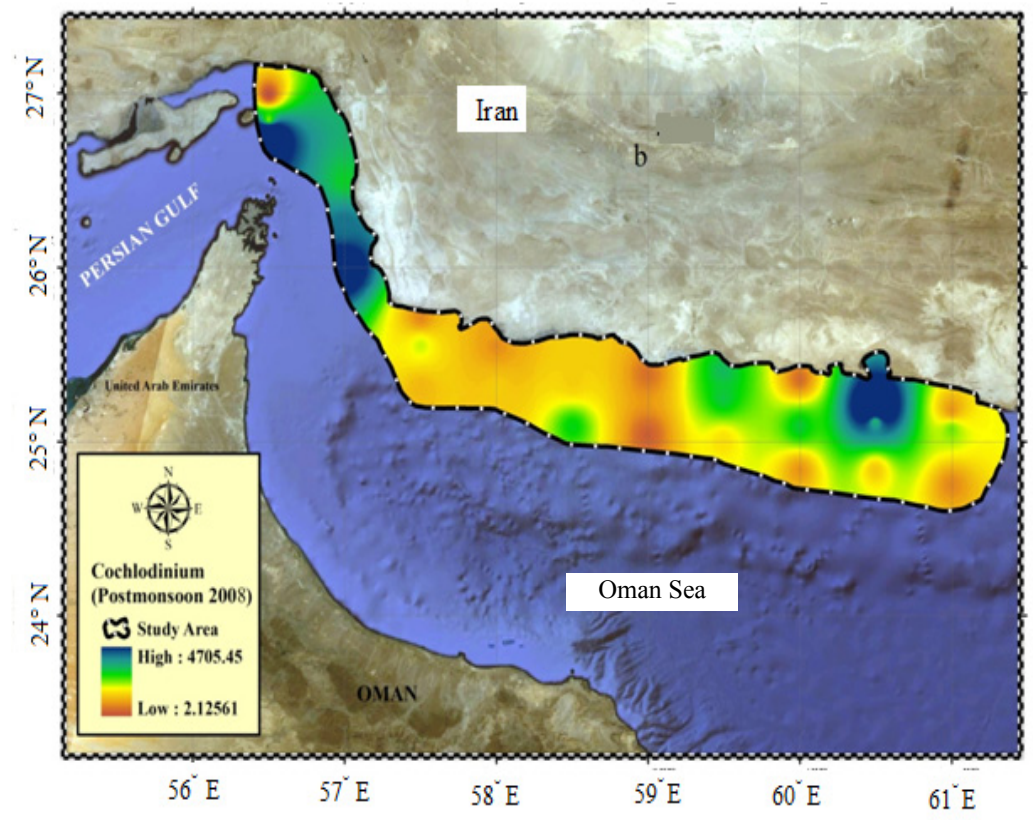

(b)

Fig. 7 Spatial and temporal variation of Cochlodinium polykrikoides in the study area: (a) during pre-monsoon season; (b) during post-monsoon season.

According to Fig. 7, the highest abundance in the pre-monsoon was recorded in the eastern part (T10) in the offshore zone, but in the post-monsoon season, the abundance was greater in the coastal waters. During the post-monsoon season, Cochlodinium polykrikoides spread to other places, especially around $\mathrm{T} 1$ to $\mathrm{T} 4$ (western part). Spatially in the eastern part of Oman Sea, the abundance was greater in the offshore zone, while in the western region, there was a greater abundance in the coastal zone. The outbreak of Cochlodinium poykrikoides was firstly observed in offshore waters before spreading into the coastal 
waters coincided with water discoloration and bloom of species.

Cochlodinium polykrikoides, which was first recorded in this study area, had been reported previously in many Asian countries such as Korea, Japan, Hong Kong, Philippine and Malaysia [15-18].

Fatemi et al. [19] mentioned that Cochlodinium polykrikoides bloomed in the Persian Gulf for the first time in September 2008. Hamzei et al. [20] also observed these species in September 2008 from the south of Oman Sea which spread to other areas of the Oman Sea, which include the Strait of Hormuz and the Persian Gulf. Oman Sea then stretched to other places. All the reported studies in this area observed discoloration of water and blooms in the region which coincided with a great deal of damage to the marine ecosystem and mortality of invertebrate organisms and fish. During the pre-monsoon period (April) of this current study, Cochlodinium polykrikoides occurred in low abundance without any water discoloration [21]. Based on the existing data and interpretation of MODIS (moderate-resolution imaging spectroradiometer) Aqua, satellite images mention that present Cochlodinium polykrikoides from Oman coasts in Arabian Sea and after moving toward the south of Oman Sea via marine flow of water by mesoscale eddies to the northern Sea of Oman and northern coasts of Strait of Hormuz are extended.

Conditions that favor bloom of harmful algae are important to be considered. On the west Florida coast, while Karenia mikimotoi blooms appeared to start offshore; they spread towards inshore during upwelling when favorable winds indicate that a new bloom will occur [22]. This correlates with study where Cochlodinium polykrikoides was firstly observed in offshore waters before spreading into coastal waters. Villarea and Magana [23] reported that between 1998-2000 in coastal Texas, Kareina brevies occurred in low density in offshore waters, but high density was observed in coastal waters which coincided with fish killing. It is common that higher phytoplankton abundance and blooms occurs towards coastal waters.

\section{Conclusions}

According to the findings of this study, management of coastal waters is very important because usually algal bloom occurred in this zone. This cause showed economic damage and effect on marine ecosystems, as well as other organisms. This in turn has effect on tourism and the health of people and society.

\section{References}

[1] Steidinger, K. A., and Tangen, K. 1997. "Dinoflagellates." In Identifying Marine Phytoplankton, edited by Tomas, C. R. London: Academic Press.

[2] Azanza, R. V., David, L. T., Borja, R. T., Baula, I. U., and Fukuyo, Y. 2008. "An Extensive Cochlodinium Bloom along the Western Coast of Palawan, Philippines." Harmful Algae 7: 324-30.

[3] Iwataki, M., Kawami, H., Mizushima, K., Mikulski, C. M., Doucette, G. J., Relox, Jr. J. R., Anton, A., Fukuyo, Y., and Matsuoka, K. 2008. "Phylogenetic Relationships in the Harmful Dinoflagellate Cochlodinium polykrikoides (Gymnodiniales, Dinophyceae) Inferred from LSU rDNA Sequences." Harmful Algae 7: 271-7.

[4] Matsuoka, K., Iwataki, M., and Kawami, H. 2008. "Morphology and Taxonomy of Chain-Forming Species of the Genus Cochlodinium (Dinophyceae)." Harmful Algae 7: 261-70.

[5] Gárate-Lizárraga, I., López-Cortés, D. J., Bustillos-Guzmán, J. J., and Hernández-Sandoval, F. 2004. "Blooms of Cochlodinium polykrikoides (Gymnodiniaceae) in the Gulf of California, Mexico." Revista de Biologia Tropical 52: 51-8.

[6] Matsuoka, K., Takano, Y., Kamrani, E., Rezai, H., Puthiyedathu, S. T., Al-Gheilani, H. M., Khalifa, M., Dongfang, Y., and Zhenqing, M. 2010. "Study on Cochlodinium polykrikoides Margalef (Gymnodiniales, Dinophyceae) in the Oman Sea and the Persian Gulf from August 2008 to August 2009." Current Development in Oceanography 1: 153-71.

[7] Rensel, J. E., and Whyte, J. N. C. 2003. "Finfish Mariculture and Harmful Algal Blooms." Monographs on Oceanographic Methodology 11: 693-722.

[8] Tomas, R. C., Hasle, R. G., Steidinger, K. A., and Tangen, K. 1996. Identificaton Marine Diatom and Dinoflagellates. California, USA: Academic Press. 
[9] Horner, R. A. 2003. A Taxonomic Guide to Some Common Marine Phytoplankton. Bristol, England: Biopress Ltd..

[10] Al-Kandari, M., Al-Yamani, F., and Al-Rifel, K. 2009. Marine Phytoplankton Atlas of Kuwait's Waters. Kuwait: Kuwait Institute for Scientific Research.

[11] Hoppenrath, M., Elbrachter, M., and Drebes, G. 2009. Marine Phytoplankton. Stuttgart, Germany: Schweizerbart Science Publisher.

[12] Al-Yamani, F. 2009. Our Beautiful Arabian Sea. Kuwai: Kuwait Institute of Scientific Research.

[13] Al-Yamani, F., and Saburova, M. A. 2010. Illustrated Guide on the Flagellate. Kuwai: Kuwait Institute of Scientific Research.

[14] Norusis, M. J. 2003. SPSS 12.0 Statical Producers Companion. Mishawaka, USA: Prentice Hall.

[15] Anton, A., Teoh, P. L., Mohd-Shaleh, S. R., and Mohammad-Noor, N. 2008. "First Occurrence of Cochlodinium Blooms in Sabah, Malaysia." Harmful Algae 7: 331-6.

[16] Heil, C. A., Glibert, P. M., Al-Sarawl, M., Faraj, M., Behbehani, M., and Husain, M. 2001. "First Record of a Fish-Killing Gymnodinium sp Bloom in Kuwait Bay, Arabian Sea: Chronology and Potential Causes." Marine Ecology Progresss Seiesr. 214: 15-23.

[17] Teen, L. M. P., Gires, U., and Lewa, C. P. 2012. "Harmful Algal Blooms in Malaysian Waters." Sains Malays 41: 1509-15.
[18] Kim, C.-J., Kim, H.-G., Kim, C.-H., and Oh, H.-M. 2007. "Life Cycle of the Ichthyotoxic Dinoflagellate Cochlodinium polykrikoides in Korean Coastal Waters." Harmful Algae 6: 104-11.

[19] Fatemi, S., Nabavi, S. B., Vosoghi, G., Fallahi, M., and Mohammadi, M. 2012. "The Relation between Environmental Parameters of Hormuzgan Coastline in Persian Gulf and Occurrence of the First Harmful Algal Bloom of Cochlodinium polykrikoides (Gymnodiniaceae)." Iranian Journal Fisheries Sciences 11: 475-89.

[20] Hamzei, S., Bidokhti, A., Mortazavi, M., Gheiby, A., Ebrahimi, M., and Saraji, F. 2012. "Field Study of the 2008-2009 Red Tide in the Northern Strait of Hormuz." Life Sciences. J. 9: 4727-33.

[21] Stumpf, R. P., and Tomlinson, M. C. 2005. "Remote Sensing of Harmful Algal Blooms." In Remote Sensing of Coastal Aquatic Environments, edited by Miller, R. L., Del Castillo, C. E., and McKee, B. A. Dordrecht: Springer.

[22] Stumpf, R., Culver, M., Tester, P., Tomlinson, M., Kirkpatrick, G., Pederson, B., Truby, E., Ransibrahmanakul, V., and Soracco, M. 2003. "Monitoring Karenia Brevis Blooms in the Gulf of Mexico Using Satellite Ocean Color Imagery and Other Data." Harmful Algae 2: 147-60.

[23] Villarea, T. A., and Magana, H. A. 2003. A Red Tide Program for Texas Coastal Waters. Report, Unviersity of Texas, Texas. 